\title{
THE
}

\section{Ecological and socioeconomic impacts of invasive alien species in island ecosystems}

Jamie K. Reaser

Laura A. Meyerson

University of Rhode Island, lameyerson@uri.edu

Quentin Cronk

Maj De Poorter

L. G. Eldrege

See next page for additional authors

Follow this and additional works at: https://digitalcommons.uri.edu/nrs_facpubs

Terms of Use

All rights reserved under copyright.

\section{Citation/Publisher Attribution}

REASER, J., MEYERSON, L., CRONK, Q., DE POORTER, M., ELDREGE, L., GREEN, E., . . VAIUTU, L. (2007). Ecological and socioeconomic impacts of invasive alien species in island ecosystems. Environmental Conservation, 34(2), 98-111. doi:10.1017/S0376892907003815

Available at: https://doi.org/10.1017/S0376892907003815

This Article is brought to you for free and open access by the Natural Resources Science at DigitalCommons@URI. It has been accepted for inclusion in Natural Resources Science Faculty Publications by an authorized administrator of DigitalCommons@URI. For more information, please contact digitalcommons-group@uri.edu. 


\section{Authors}

Jamie K. Reaser, Laura A. Meyerson, Quentin Cronk, Maj De Poorter, L. G. Eldrege, Edmund Green, Moses Kairo, Pepetua Latasi, Richard N. Mack, John Mauremootoo, Dennis O'Dowd, Warea Orapa, Soetikno

Sastroutomo, Alan Saunders, Clare Shine, Sigurdur Thrainsson, and Leliua Vaiutu 


\title{
Ecological and socioeconomic impacts of invasive alien species in island ecosystems
}

\author{
JAMIE K. REASER ${ }^{1 *}$, LAURA A. MEYERSON ${ }^{2}$, QUENTIN CRONK $^{3}$, MAJ DE POORTER $^{4}$, \\ L.G. ELDREGE ${ }^{5}$, EDMUND GREEN ${ }^{6}, \operatorname{MOSES~KAIRO}{ }^{7}$, PEPETUA LATASI ${ }^{8}$, RICHARD N. \\ MACK $^{9}$, JOHN MAUREMOOTOO ${ }^{10}$, DENNIS O'DOWD ${ }^{11}$, WAREA ORAPA ${ }^{12}$, SOETIKNO \\ SASTROUTOMO ${ }^{13}$, ALAN SAUNDERS ${ }^{14}$, CLARE SHINE ${ }^{15}$, SIGURDUR THRAINSSON ${ }^{16}$ \\ AND LELIUA VAIUTU ${ }^{17}$ \\ ${ }^{1}$ Ecos Systems Institute, c/o Ravens Ridge Farm, 1207 Bull Yearling Road, Stanardsville, Virginia 22973, USA, ${ }^{2}$ The University of Rhode Island, \\ Department of Natural Resources Science, 1 Greenhouse Road, Kingston, RI 02881, USA, ${ }^{3}$ University of British Columbia Botanical Garden and \\ Centre for Plant Research, 206 Campbell Building, 6804 SW Marine Drive, British Columbia, Canada, ${ }^{4}$ Centre for Invasive Species Research \\ (CISR), University of Auckland, Auckland, Nem Zealand, ${ }^{5}$ Bishop Museum, 1525 Bernice Street, Honolulu, HI 96817, USA, ${ }^{6}$ Marine and \\ Coastal Programme, UNEP World Conservation Monitoring Centre, 219 Huntingdon Road, Cambridge, UK, ${ }^{7}$ Center for Biological Control, \\ Florida A EM University, 310-South Perry-Page, Tallahassee, FL 32307, USA, ${ }^{8}$ Ministry of Environment, Energy and Tourism, Tuvalu, ${ }^{9}$ School \\ of Biological Sciences, Washington State University, Pullman, WA 99164-4236, USA, ${ }^{10}$ CAB International-Africa Regional Centre, PO Box \\ 633-00621, Nairobi, Kenya, ' Australian Centre for Biodiversity, School of Biological Sciences, PO Box 18, Monash University, Victoria 3800, \\ Australia, ${ }^{12}$ Secretariat of the Pacific Community, Private Mail Bag, Suva, Fiji Islands, ${ }^{13}$ CAB International, Southeast Asia Regional Centre, \\ Glasshouse No. 2, Opposite Block G Mardi Complex, PO Box 210UPM Serdang, Selangor, Malaysia 43400, ${ }^{14}$ Cooperative Initiative on Invasive \\ Alien Species on Islands, School of Environmental and Marine Science, University of Auckland, Auckland, Nem Zealand, ${ }^{15}$ World Conservation \\ Union (IUCN), Environmental Lam and Policy, 37 Rue Erlanger, 75016, Paris, France, ${ }^{16}$ Ministry for the Environment, Vonarstraeti 4, IS-150 \\ Reykjavik, Iceland, and ${ }^{17}$ Agriculture Plant Protection Office, Department of Agriculture, Tuvalu \\ Date submitted: 11 June 2004 Date accepted: 28 February 2007 First published online 25 May 2007
}

\section{SUMMARY}

Minimizing the impact of invasive alien species (IAS) on islands and elsewhere requires researchers to provide cogent information on the environmental and socioeconomic consequences of IAS to the public and policy makers. Unfortunately, this information has not been readily available owing to a paucity of scientific research and the failure of the scientific community to make their findings readily available to decision makers. This review explores the vulnerability of islands to biological invasion, reports on environmental and socioeconomic impacts of IAS on islands and provides guidance and information on technical resources that can help minimize the effects of IAS in island ecosystems. This assessment is intended to provide a holistic perspective on islandIAS dynamics, enable biologists and social scientists to identify information gaps that warrant further research and serve as a primer for policy makers seeking to minimize the impact of IAS on island systems. Case studies have been selected to reflect the most scientifically-reliable information on the impacts of IAS on islands. Sufficient evidence has emerged to conclude that IAS are the most significant drivers of population declines and species extinctions in island ecosystems worldwide. Clearly, IAS can also have significant socioeconomic impacts directly (for example human health) and indirectly through their

\footnotetext{
${ }^{*}$ Correspondence: Dr Jamie K. Reaser Tel: +1 4349909494 e-mail: ecos@nelsoncable.com
}

effects on ecosystem goods and services. These impacts are manifest at all ecological levels and affect the poorest, as well as richest, island nations. The measures needed to prevent and minimize the impacts of IAS on island ecosystems are generally known. However, many island nations and territories lack the scientific and technical information, infrastructure and human and financial resources necessary to adequately address the problems caused by IAS. Because every nation is an exporter and importer of goods and services, every nation is also a facilitator and victim of the invasion of alien species. Wealthy nations therefore need to help raise the capacity of island nations and territories to minimize the spread and impact of IAS.

Keymords: biological invasion, environmental impacts, invasive alien species, islands, socioeconomic impacts

\section{INTRODUCTION}

Globalization has brought social and economic benefits to many people, but it has also presented new challenges of which invasive alien species (IAS) are among the most significant. At no time in history has the rate of biological invasion (Mack et al. 2000) or the diversity and volume of these invaders been so high and the consequences so great (Mooney \& Hobbs 2000; McNeely et al. 2001; Reaser et al. 2003a). Islands have long been considered to be under intense ecological threat from the spread of alien species (Elton 1958; Donlan et al. 2003), and modern impacts also have potentially severe consequences for the more than 50 million people who live in small island developing states (SIDS; UN [United Nations] 
2003). Thwarting IAS on islands and elsewhere requires cogent information on the environmental and socioeconomic consequences of IAS for the public and policy makers (Ewel et al. 1999; CBD [Convention on Biological Diversity] 2002; Ruiz \& Carlton 2004). This information has not been readily available owing to a paucity of scientific research and failure of the scientific community to communicate its findings to policy makers in a manner that fosters well-informed decisions (Waage \& Reaser 2001; Meyerson \& Reaser 2002).

National and international agencies increasingly recognize the need for more accurate and timely data on the impacts of IAS. Because of the common vulnerability of island ecosystems and the people who depend upon them, the protection of island biodiversity has become a priority for the UN (see URL http://islands.unep.ch/). The CBD (URL http://www.biodiv.org) has repeatedly called on member countries to give particular attention to biodiversity conservation and sustainable development on islands and in other geographically and evolutionarily isolated ecosystems. There is an urgent need for sound advice on the impacts of IAS on island species.

Here we review the vulnerability of islands to biological invasion, report on environmental and socioeconomic impacts of IAS on islands, and provide information on resources that can help minimize the effects of IAS in island ecosystems. This assessment is intended to provide a holistic perspective on island-IAS dynamics, enable biologists and social scientists to identify information gaps that warrant further research, and serve as a primer for policy makers seeking to make decisions that will help minimize the impact of IAS on island systems.

While much of the information on the consequences of IAS on islands remains anecdotal, we have relied primarily on peerreviewed research as well as projects with which we are personally familiar. The reported research on IAS impacts on islands is primarily from relatively well-populated and economically prosperous island states and nations (such as Hawai' $i$ and New Zealand). We have thus complemented these studies with observations and research findings contributed to the Global Invasive Species Programme's (GISP) international workshops by both ourselves and others working in the SIDS context.

\section{ISLAND ECOSYSTEMS}

The geographic isolation of oceanic islands has facilitated the establishment and evolution of distinct and limited arrays of species as compared with continental systems. The presence of the surrounding marine environment and physical distance from the mainland limit the number and taxa of organisms that can naturally reach and colonize islands. In many instances, groups such as large-seeded plants and large mammals are, as a result, absent from islands' endemic biotas (Mueller-Dombois 1981; Loope \& Mueller-Dombois 1989). For example, Hawai'i lacks native mammals (with the exception of a bat) and two-thirds of the world's insect orders (Loope \& MuellerDombois 1989). The long history of isolation coupled with the high topographic, and thus microclimatic, diversity typical of many, especially volcanic, islands has led to the evolution of organisms that are endemic to islands or island chains (Mueller-Dombois 1981). In Mauritius, for example, 70\% of the species of flowering plants, $80 \%$ of the bird species and $90 \%$ of the reptile species are endemic (Mauremooto 2003).

Compared with organisms found on the mainland, island species are generally less vagile (for example flightless birds), comprise fewer populations and/or have smaller total population sizes. These characteristics, coupled with isolation and endemism, make island ecosystems especially sensitive to disturbance, and island species can be vulnerable to extinction at rates that often exceed those of continental species (Mueller-Dombois 1981; Loope \& Mueller-Dombois 1989; D'Antonio \& Dudley 1995). Thus, 90\% of Hawai'i's flora is endemic and approximately $25 \%$ has been listed as threatened or endangered (Harrington \& Ewel 1997).

\section{INVASIVE ALIEN SPECIES}

IAS are one of the most significant drivers of environmental change worldwide (Sala et al. 2000; McNeely et al. 2001). They have been implicated in the endangerment of specific species (Wilcove et al. 1998), degradation of aquatic and terrestrial environments (Cartlon 2001; D'Antonio \& Kark 2002) and the alteration of biogeochemical cycles (D'Antonio \& Vitousek 1992; Mack \& D'Antonio 1998). They contribute to social instability and economic hardship, consequently placing constraints on the conservation of biodiversity, sustainable development and economic growth (McNeely 2001; Pimentel el al. 2001; MEA [Millennium Ecosystem Assessment] 2005; GISP 2006). The globalization of trade, travel and transport is greatly increasing the number of IAS that are being moved around the world, as well as the rate at which they are moving (McNeely et al. 2001; Burgiel et al. 2006). At the same time, changes in climate and land use are rendering some habitats, even the best protected and most remote natural areas (see Simberloff 2000a; O'Dowd et al. 2003), more susceptible to biological invasion (Mooney \& Hobbs 2000).

Article 8(h) of the CBD calls on Parties to 'as far as possible and as appropriate: Prevent the introduction of, control or eradicate those alien species which threaten ecosystems, habitats or species.' At the sixth Conference of the Parties (COP 6), Parties adopted guiding principles and a programme of work for the implementation of Article 8(h) (Decision VI/23; CBD 2002). This decision recognized IAS as primary threats to biodiversity in SIDS and urged bilateral donors and other funding sources to make funding for development and implementation of IAS strategies and actions in geographically and evolutionarily isolated ecosystems an urgent priority.

\section{ISLANDS AND INVASIVE ALIEN SPECIES}

We explore here the vulnerability of islands to biological invasion, report on known environmental and socioeconomic impacts of IAS on islands, and provide information on 
resources that can help minimize the effects of IAS in island ecosystems.

\section{Vulnerability}

Given the intrinsic complexity and dynamism of most natural systems, scientists and policy makers find it useful to assess the vulnerability (risk of damage) of ecosystems and their components to specific natural and anthropogenic threats. This approach enables projections regarding the future condition of ecosystem goods and services, as well as decisions to be made that minimize risks to these outputs, thus maximizing the benefits over the costs to society.

Islands have often been regarded as more susceptible to invasion by alien species than mainland ecosystems (Carlquist $1965,1974)$, however, with the exception of some plant taxa (Lonsdale 1999), this generalization appears to be poorly supported (D'Antonio \& Dudley 1995; Denslow 2003; Gaston et al. 2003). For example, there are equal numbers of reports of the invasion of woody plants from continents as from oceanic islands (Binggeli 1996), and no difference in the ability of birds to invade islands as compared to continents (Blackburn \& Duncan 2001). However, susceptibility to biological invasion does not necessarily coincide with vulnerability to the effects of IAS, and islands are more susceptible to the effects of invaders (D'Antonio \& Dudley 1995).

Ideally, the vulnerability of island ecosystems to IAS needs to be considered from three main perspectives:

(1) risk of the $(a)$ introduction, $(b)$ establishment and $(c)$ spread of IAS;

(2) intrinsic resilience of island ecosystems to biological invasion; and

(3) extrinsic resilience of island ecosystems to biological invasion.

The risk of the introduction, establishment and spread of IAS in island systems depends on a number of ecological and socioeconomic factors (such as climate, resource availability and demand for certain goods and services) that are context specific and often inter-related (Mack et al. 2000). For example, the major pathways of biological invasion into island ecosystems are diverse (for example ballast water, hull fouling, food supply and aesthetics; Ruiz \& Carlton 2004) and are strongly influenced by an island nation's or territory's trade status (Burgiel et al. 2006). The risks of a harmful nonnative species becoming established are especially high if the ecosystem of origin and ecosystem of introduction are climatically similar (Lonsdale 1999; NRC [National Research Council] 2002), propagule pressure is sufficient to enable introduction of a viable population (Lockwood et al. 2005; Drake \& Lodge 2006; Duggan et al. 2006) and the ecosystem into which the non-native species is introduced is lacking in other species (predators, competitors, pathogens and parasites) capable of controlling its population growth (Lake \& O'Dowd 1991; Green et al. 2004; Blumenthal 2005; Colautti et al. 2005). In southern oceanic islands, energy availability, or possibly variations in climate-matching, have been responsible for differences in invasion (Chown et al. 2005).

The extent to which an invasion causes damage depends on how and to what degree the indigenous biotic community is disrupted (Mueller-Dombois 1981; Mooney \& Hobbs 2002). The intrinsic resilience of island ecosystems is determined by the ecological factors that enable them to resist or tolerate alien species (for example existence of refugia, native predators and niche differentiation). An island ecosystem's extrinsic resilience is dictated by external forces (for example natural disasters such as hurricanes, but more often socioeconomic factors) that influence its integrity. Many of these forces are dynamic and can influence resilience in both predictable (for example trade patterns) and unprecedented (for example anthropogenic climate change) ways.

The concept of ecosystem resilience has been rigorously debated and has recently become the focus of numerous studies evaluating the vulnerability of specific ecosystems to biological invasion (Loope \& Mueller-Dombois 1989; Simberloff 1995, 2000b; Chapin et al. 2000). Invasion resistance in specific ecosystems and taxonomic groups has been evaluated by Simberloff (1986; insects in Hawai'i), Lake and O'Dowd (1991; giant African land snail on Christmas Island), Duncan (1997; birds in New Zealand), Vidal et al. (1998; flora off southeast France), Stachowicz et al. (1999; marine systems), Sol (2000; birds in New Zealand and Hawai'i), Gabriel et al. (2001; springtails on Marion Island near Antarctica) and Sara and Morand (2002; mammals on Mediterranean islands). Despite the recent development of this area of IAS biology, a wide range of factors (such as community type, disturbance history and climate) clearly influence the invasibility of ecosystems. However, these factors are not necessarily the same across invading taxonomic groups.

The overall impact $(I)$ of an invader on a specific geographic scale equals the total area occupied by the species $(R)$ multiplied by the abundance of the IAS involved $(A)$ and further multiplied by a measure $(E)$ of the impact per individual or per unit of biomass (Parker et al. 1999). Thus, $I=R \times A \times E$. In practice, however, few rigorous frameworks for quantitative risk analysis, or data, are currently available to reliably predict the invasive potential of organisms or the resilience of ecosystems (Leung et al. 2002). Predictive (and post hoc) analysis of impacts is further complicated because variables such as abundance and range are difficult to define and measure retrospectively, variables are not independent, and the relationship among the variables can be non-linear (see NRC 2002). Nevertheless, there have been numerous attempts to address these gaps and challenges (see Kolar \& Lodge 2002; NRC 2002).

\section{Impacts}

Historically, habitat destruction was appropriately regarded as the most significant factor affecting island biodiversity (Bramwell \& Bramwell 1974). In New Zealand, for example, habitat destruction reduced forest cover from $68 \%$ to $14 \%$ 
over a 200-year period (Kuschel 1975). However, there is increasing evidence that IAS have become the most significant driver of population declines and species extinctions in island ecosystems. Biological invaders may soon surpass habitat loss as the main cause of environmental degradation globally (Chapin et al. 2000) and are now likely the main cause of extinctions in island ecosystems (Clout \& Veitch 2002). Furthermore, the interacting influences of habitat destruction, global climate change and IAS are likely to exacerbate the challenges posed by IAS (Mooney \& Hobbs 2002).

The impacts of IAS on island biodiversity need to be assessed across multiple levels of organization, including ecosystems, habitats, species and genes. Multiple interactions (such as energy flows, nutrient cycling and hybridization) can occur across these categories and, ultimately, ecosystem goods and services (for example potable water, medicinal plants and crop protection) are the tangible societal benefits derived from these interactions (Daily 1997).

In general, the environmental effects of IAS on islands (and other ecosystems) can:

- occur at any level or across levels of biotic organization;

- result from direct or indirect influences, or both, of the IAS;

- occur immediately or years after the introduction (i.e. only after a prolonged lag time since arrival);

- persist for the short- or long-term;

- act synergistically to magnify or amplify other impacts on the system (including habitat destruction; see Sala et al. 2000);

- be so subtle that they are not readily perceived, but be cumulative over time; and/or

- interact and have cascading effects (i.e. effects that trigger additional effects throughout the system).

In all ecosystems, IAS can cause direct and indirect harm to one or more sectors of human society (MEA 2005). However, even though the effects of IAS on the environment, human health or the economy can be significant, there is often a constituency who seek to protect (for example for animal welfare) or even propagate the species (for food for local consumption or export). This desire can lead to conflicts over the eradication and control of the IAS (Mack et al. 2000; McNeely 2001) and increase the demand for resource managers to evaluate the perceived costs (impacts) compared with benefits of the IAS to society (Perrings et al. 2000; Pimentel 2002). Given the paucity of reliable quantitative information for cost-benefit analyses, this time-consuming task can inadvertently reduce the ability of resource managers to respond to IAS soon enough to eradicate them (Reaser et al. 2003b). However, when evidence of the impacts can be obtained and communicated reliably and rapidly, the information can motivate support from a wide range of constituencies (Veitch \& Clout 2002; Donlan et al. 2003).

Below we provide case studies of the ecological impacts on IAS to islands at the major levels of organization of nature. Additional case studies prepared by GISP and GISP's partners can be found in Sherley (2000), Wittenberg and Cock
(2001), Hernandez et al. (2002), Reaser et al. (2002), Veitch and Clout (2002), Mauremooto (2003), Meyerson \& Reaser (2003), Shine et al. (2003a, b), MacDonald et al. (2004a, b) and Pallewatta et al. $(2004 a, b)$.

\section{Ecological impacts}

\section{Populations}

IAS are sometimes introduced or spread into habitats that support species that are close relatives of the IAS. If the IAS interbreed with the native species, the genetic makeup of one or both species can be altered. Multiple consequences are possible, including reduced survivorship of either species, creation of a highly successful 'super invader' (Rhymer \& Simberloff 1996) or hybrids that are more susceptible to pathogens and become new hosts (i.e. the hybrid bridge hypothesis; Floate \& Whitham 1993). Whether the low genetic diversity of some island species makes them more susceptible to the effects of IAS remains to be demonstrated (Loope \& Mueller-Dombois 1989). There are several island cases of extinction by hybridization (Levin et al. 1996).

Mallard ducks (Anas platyrhynchos) are native to North America but have been introduced around the world, often for hunting. There are numerous examples of hybridization between the mallard and other ducks that have resulted in reduced populations of native or endemic species. For example, hybridization with mallards has been detrimental to the New Zealand grey duck (Anas superciliosa superciliosa) and Hawaiian duck (Anas wyvilliana) (Rhymer \& Simberloff 1996).

Hybridization with IAS may be a particularly significant threat to rare species on islands, thereby diluting the native gene pool to the point of extinction in a hybrid swarm. Examples of island plants threatened by hybridization with invasive plants include the common butterwort (Pinguicula vulgaris), which is locally rare in the British Isles, and Canary madrona (Arbutus canariensis) and Hawaiian ebony (Gossypium tomentosum), which are endemic to the Canary and Hawaiian Islands, respectively (Levin et al. 1996).

\section{Species}

IAS can influence species diversity, richness, composition, abundance and interactions (including mutualisms). The direct effects of IAS at the species level occur through processes such as predation on, competition with and parasite transmission to individual organisms (Daszak et al. 2000; Blumenthal 2005; Colautti et al. 2005). These processes can eventually cause population declines and resultant species extirpations and extinctions. Prehistoric and historic extinctions on islands have been well documented (for example Milberg \& Tyrberg 1993; Alcover et al. 1998; Donazar et al. 2005). And, while the number of invasions that have thus far resulted in known species extinctions is small (Simberloff 2001), there are several well documented cases (Coote \& Loeve 2003): the losses are certainly higher for islands than mainland systems (D'Antonio \& Dudley 1995). The impact of 
predatory IAS on island biota is particularly well documented and striking (for example Cheke 1987; Johnson \& Stattersfield 1990; see below). Species-level changes can also be induced by the effects of IAS at other levels of biotic organization. In most instances where species-level changes are evident, however, little or no assessment of the consequences for habitats and ecosystem function has been made (D'Antonio \& Dudley 1995).

On Australian islands, the presence of introduced foxes (Vulpes vulpes) and cats (Felis silvestris catus) correlates with native mammal extinctions; extinctions on more arid islands have been largely attributable to feral cats. Native mammals were most vulnerable to extinctions on islands that lacked rock piles as common habitat and in instances in which the species was large-bodied and ground dwelling (Burbidge \& Manly 2002).

Overgrazing and overbrowsing by introduced herbivores has caused both direct and indirect biodiversity loss in countless island systems. For example, the introduction of the domestic goat (Capra hircus) to islands has had profound effects on plant diversity, abundance and community structure and composition (Campbell \& Donlan 2005). In the Hawaiian islands, goats have reduced or eliminated entire populations of native plants, and facilitated soil erosion and establishment of invasive plants (Mueller-Dombois \& Spatz 1975). In the Galápagos, Scalesia baurii spp. hopkinsii (Asteraceae) and Opuntia galapageia var. galapageia (Cactaceae) stands on Pinta Island had nearly collapsed after 18 years of goat browsing (Hamann 2004), which also reduced the diversity and composition of plants and associated invertebrates on Volcan Alcedo (Desender et al. 1999). On the California Channel and North-western Baja California islands, defoliation and erosion caused by goats and rabbits have had severe impacts, including potentially serious effects on seabird populations (McChesney \& Tershy 1998).

The rosy wolf snail (Euglandia rosea) exemplifies IASinduced extinctions on islands; it is highly predatory, takes less than a year to mature, produces more than 600 eggs per individual per year and has a lifespan of up to five years (Simon 1987). E. rosea was introduced from the southern USA to Pacific islands as a biocontrol agent for the invasive giant African snail (Achatina fulica). While some success controlling A. fulica has been reported, E. rosea is more widely recognized for the large numbers of extinctions that it has caused or contributed to, namely 24 of 106 endemic snail species in Mauritius, seven snail species in Moorea (French Polynesia) and at least 15 endemic species in Hawai'i (Stein \& Flack 1996).

\section{Habitats}

IAS can lead to the fragmentation, destruction, alteration and even the complete replacement of habitats. In turn, these effects on habitats often result in consequences for even more species and ecosystem processes, leading to the functional collapse of the native ecosystem (O'Dowd et al. 2003).
Introduced mangroves (such as Rhizophora mangle) have had significant consequences for the native biota of Hawai'i, by altering coastline hydrodynamics and nearshore sedimentation. The spread of mangroves has led to habitat loss for wetland birds, including the endemic Hawaiian stilt (Himantopus mexicanus knudseni), Hawaiian coot (Fulica americana alai) and Hawaiian duck (Anas myvilliana). Mangrove habitats also provide refugia for shorebird predators, which include invasive rats (Rattus spp.) and the mongooses (Herpestes spp.), and non-native marine species, such as the mangrove crab (Scylla serrata) (Demophoulis \& Smith 2001).

In 1937, Miconia calvescens, a large Andean tree, was introduced to French Polynesia. Since that time, it has significantly altered the forests of French Polynesia and other Pacific islands. Its large leaves ( $>1 \mathrm{~m}$ long) reduce the light interception by the seedlings of native forest species, and its shallow roots promote erosion and landslides. Each mature tree can produce millions of tiny seeds per year that are readily spread by birds, on construction equipment or on hiking boots. Particularly troublesome is the invader's spread to mountainous crags up to $1300 \mathrm{~m}$ on Tahiti, a location in which eradication has been impossible. By the 1980s, $M$. calvescens dominated $70 \%$ of the forest habitats on Tahiti and had also invaded the neighbouring island of Moorea (Meyer \& Florence 1996). It was reported in Hawaiian watersheds in the 1960 s, but because management measures were not initiated until the 1990s, control of the plant now poses a formidable challenge (Shine et al. 2003b).

In the Galápagos archipelago, the plant species introduced since the island's discovery in 1535 (c. 600 spp.) now outnumber the native flora (c. $500 \mathrm{spp}$.). The arrival of this alien flora equates to a rate of more than one species per year, while the natural rate of arrival of new plant species on the islands is about one species every 10000 years. The alien species are primarily cultivated plants, but also include plants brought in unintentionally. By 2001, 55\% of the alien species did not appear to be becoming established, but $45 \%$ had naturalized. Of the latter, $7 \%$ are invasive and $20 \%$ are potentially invasive (Magee et al. 2001). Many of the IAS (particularly trees, climbers and grasses) are aggressively outcompeting endemic and native Galápagos plants, altering the unique habitats that host numerous endemic animal species (Tye et al. 2002). Quinine tree (Cinchona pubescens), air plant (Bryophyllum pinnatum), lantana (Lantana camara), elephant grass (Pennisetum purpureum), guava (Psidium guajava) and hill raspberry (Rubus niveus) are among the worst invaders, and the four human-inhabited islands are the most significantly affected (McMullen 1999).

\section{Ecosystems}

Effects of IAS on ecosystems can be especially difficult to measure. On islands, known ecosystem-level impacts of IAS include the alteration of trophic structure, shifts in demands for resources (such as water and nutrients), alteration of resource availability or rates of resource renewal 
and changes in the disturbance regime of an ecosystem (D'Antonio \& Dudley 1995; O'Dowd et al. 2003). The direct changes in trophic structure resulting from IAS occur more often or with greater severity on islands than on continents because islands typically have poorly represented groups of organisms, especially predators and large vertebrate grazers (D'Antonio \& Dudley 1995).

Large-scale and perhaps irreversible ecosystem alterations can occur when one invader facilitates the invasion or compounds the effects of other IAS. For example, on islands, native tree species may be less vulnerable than IAS to natural disturbances, such as cyclones and hurricanes. Thus, when these disturbances occur in invaded landscapes, soil erosion, evaporation rates and other ecosystem processes can be altered for prolonged periods (Vitousek et al. 1997; Mooney \& Hobbs 2000). In Hawai'i, the introduction of earthworms and some introduced plants (for example Psidium cattleianum and Passiflora mollissima) facilitated the establishment of feral pigs (Sus scrofa) (Stone \& Loope 1987). The pigs' digging has exposed mineral soil, thereby enabling numerous plants to invade forest understoreys that were previously alienplant free (Loope \& Mueller-Dombois 1989). Furthermore, introduced earthworms are found in higher densities under the invasive N-fixing tree Myrica faya, greatly facilitating the incorporation of $\mathrm{N}$ in soils and paving the way for other invasive species (Aplet 1990).

On tropical islands around the world, the fire cycle has commonly been altered by IAS. Throughout the islands of Oceania, for example, introduced grasses have promoted fire when their dead litter accumulates as fuel. Consequently, fires often increase the possibility for reinvasion by the current or new IAS (some of which might have been introduced for erosion control or restoration efforts). For example, several species of grasses were introduced to the Hawaiian Islands as forage for cattle. Some of the grasses spread into woodlands, where they caused a 300-fold increase in the extent of fire (D'Antonio \& Vitousek 1992; D'Antonio 2000).

Introduction of the yellow crazy ant (Anoplolepis gracilipes) and other IAS has had cascading effects throughout the ecosystems of Christmas Island in the Indian Ocean. The island has been well known internationally for its dense populations ( 1 per $\mathrm{m}^{2}$ ) of native land crabs (Gecarcoidea natalis), which migrate annually to the ocean and are dominant consumers of rainforest detritus (Green et al. 1999). The yellow crazy ant was unintentionally introduced between 1915 and 1934, but has spread rapidly in the last decade. It is continuously active, has a broad diet, and tends honeydew-producing scale insects (for example Tachardina aurantiaca), causing their populations to explode in the forest canopy. The ants kill the crabs by 'mobbing' them and spraying them with formic acid. With the loss of crabs, leaf litter has accumulated causing rapid changes in the food-web. The ant has indirect effects on other forest processes; sooty moulds growing on honeydew-covered leaves decrease photosynthesis and thus lower tree survival. The ant also affects the reproductive success of endemic fruiteating birds such as the Christmas Island thrush (Turdus poliocephalus erythropleurus), either through direct predation, habitat alteration or competition for food (O'Dowd et al. 2003).

Pollination and seed dispersal are essential processes for both native and introduced plants, including crops. Some island plants (such as the silverswords Argyroxiphium and Dubautia spp.) have evolved obligate outcrossing mechanisms and are thus threatened by any detrimental effects to their pollinators (Carr et al. 1986). In this manner, the highly aggressive Argentine ant (Linepithema humile) could be a serious threat to the specific native insect pollinators of the silversword (Argyroxiphium sandwicense subsp. macrocephalum) in Hawai'i (Cole et al. 1992).

\section{Socioeconomic impacts}

The ecological impacts of IAS on island ecosystems influence the ability of these ecosystems to provide the goods and services needed, or desired, by people. IAS can also have socioeconomic consequences when they directly affect human health or physical structures. We cite below case studies of the socioeconomic impacts of IAS on islands.

\section{Fisheries}

The mud blister worm (Polydora mebsteri) can affect the oyster aquaculture industry by reducing the health of oysters and thus their marketability. The worm drills into the shells of living oysters and other molluscs, creating a small, mud-filled pocket that looks like a blister on the inner surface of the shell. The worms were found in an oyster farm at Kahuku (Oahu, Hawai'i), having been unintentionally introduced with oysters transported from Kaneohe Bay (Hawai'i) or from fisheries on the western coast of the USA. They became established in the oyster farm's cement holding tanks and eventually put the industry out of business (Bailey-Brock \& Ringwood 1982).

\section{Agriculture}

Amami Island $\left(710 \mathrm{~km}^{2}\right)$, part of the Ryukyu Archipelago (south-western Japan), is primarily (70\%) forested and hosts numerous endemic and threatened species (Kagoshima Prefecture Office 1999). Thirty small Indian mongooses (Hespestus javanicus) are believed to have been taken from Okinawa Island (Kishida 1931; Sekiguchi et al. 2001) and released on Amami to control a highly venomous native snake known as the habu (Trimeresurus flavoviridis). Within 20 years, the mongoose population had reached 5000-10 000 individuals and their range was extending at approximately $1 \mathrm{~km}$ per year (Environment Agency 1999). The mongoose has had profound effects on agriculture (for example taro, sweet potato and watermelon) and the poultry industry, as well as biodiversity. The economic costs of damage to agriculture rose 16-fold in the three years 1994-1997.

The golden apple snail (Pomacea canaliculata) was intentionally introduced into Taiwan from Argentina in 1981, ostensibly to serve as a high-protein food source for local populations and as an export commodity for highincome countries. Instead, the snail spread through irrigation 
networks and has moved into rice fields where it feeds voraciously on young rice plants. The snail is now the primary rice pest in the Philippines. Naylor (1996) estimated that the cumulative (present-value) costs of the snail invasion to Philippine rice agriculture in 1990 were US\$ 4251200 million, even without taking into account non-market impacts such as on ecosystems and human health. The golden apple snail and its relatives currently pose a problem on many islands in Asia and the Pacific (Shine et al. 2003a, b; Pallewatta et al. 2004a, b; Joshi \& Sebastian 2006).

\section{Ornamentals}

An invasive cut throat coral (Carijoa riisei), which has polyps that resemble snowflakes, has recently started outcompeting black coral (Antipatharia) in Hawai'i. Its potential to cause significant environmental damage in both shallow and deep water reefs is now of great concern to the community of Maui and the black coral industry which serves the aquarium and souvenir trades (valued at US\$30 million annually). The invasive coral, which may have been transferred from the Caribbean on the hulls or in the ballast water of ships between 1940 and 1970, was discovered in Pearl Harbor in 1972 (Grigg 2004).

Many invasive plants in Hawai'i are emblematic of the all too common worldwide result of ornamental plant introduction. Repeatedly, species prized for horticultural value in Hawai'i (Clidemia hirta, Hedychium gardnerianum, Lantana camara, Miconia calvescens, Oxyspora paniculata, Passiflora mollisima and Pennisetum setaceum) have become serious threats to the islands' biological conservation and agriculture (Cuddihy \& Stone 1990).

\section{Infrastructure}

The Formosan subterranean or ground termite (Coptotermes formosanus) was officially recorded in Honolulu (Hawai'i) in 1913, but may have been present as early 1869. It was likely introduced from Formosa or South China when there was extensive trade in sandalwood between Hawai'i and China. In spite of its relatively limited distribution, this subterranean termite is by far the most economically damaging pest in Hawai'i; the cost to prevent or control infestations and to repair the damage has been conservatively estimated at more than US\$ 60 million a year (see URL http://pesticides. hawaii.edu/studypackets/termite.html).

\section{Tourism}

In 1995, Norway rats (Rattus norvegicus) reached Fregate Island, the Seychelles' last remaining rat-free island greater than $100 \mathrm{ha}$. The island is a critical refuge for two birds, three invertebrates and a mollusc endemic to the Seychelles. It also supports the largest populations of six species of endemic reptiles. Five years after the rats' arrival, the commercial tourist industry became so concerned about economic losses that a rat eradication programme was initiated (Merton $e t$ al. 2002). The flightless giant tenebrionid beetle (Polposipes herculeanus) was also facing impending extinction from the same IAS, but has not garnered nearly as much public attention as the loss of tourist income (Parr et al. 2000). Tourism has also been threatened on the Seychelles' Bird Island, where the yellow crazy ant (Anoplolepis gracilipes) displaced approximately 60000 pairs of sooty terns (Sterna fuscata), a main tourist attraction and economic mainstay of the island (Feare 1999).

The coqui (Eleutherodactylus coqui) is a small tree frog $(2.5 \mathrm{~cm}$ long) that is native to Puerto Rico, where it is regarded as a territorial symbol; its image adorns a wide variety of the island's souvenirs. It is well established in St Thomas and St Croix (US Virgin Islands) (Schwartz \& Henderson 1991), and was introduced to Hawai'i in the mid- to late 1990s, probably on landscaping plants from the Caribbean or Florida; it now occupies Maui and Oahu as well. While the frog is capable of devouring large numbers of endemic insects and thus may compete with native birds (Kraus et al. 1999), many islanders and tourists more readily complain about the very loud, piercing calls (nearly 100 decibels at $0.5 \mathrm{~m}$ distance; HEAR [Hawaiian Ecosystems at Risk Project] 2000) that the frog makes at night (Staples \& Cowie 2001, Shine et al. 2003a). This tiny frog is, in fact, already blamed for depressing Hawaiian real estate values in infested areas by as much as $64 \%$ (B. Kaiser, W. Pitt \& K. Burnett, personal communication 2006).

Although most tourists probably neither know or care that nearly all the plants they encounter at their island destination are aliens (for example in Hawai'i or the Seychelles), their holiday may nevertheless be adversely affected by invasive plants. The Australian tree Casuarina equisetifolia (beefwood) now skirts the shoreline on many islands in the Bahamas. Its coarse root masses provide no protection for the shoreline; many beaches are rapidly being eroded and their future as recreational sites is severely threatened (Sealey 2006).

\section{Human health}

Several species of invasive snails are known to serve as intermediate hosts of the rat lungworm (Angiostrongylus cantonensis) which can cause the fatal disease eosinophilic meningoencephalitis in humans (Lo Re \& Gluckman 2003). Both the golden apple snail (Pomacea canaliculata) and the giant African land snail (Achatina fulica) should be of concern to many island communities in the Asia-Pacific region. The latter has been both intentionally (as a potential food source) and unintentionally (contaminant of military equipment in World War II, horticulture, tiles) introduced. Despite the risk to humans, both are commodities in the pet and aquaria trade (see URL http://www.igor.demon.co.uk/Brixton).

Invasive plants on islands may produce a cornucopia of organic compounds, many of which can induce toxic and even lethal effects in humans. Parthenium weed (Parthenium hysterophorus) is amongst the most serious of these species because routine contact with the annual induces allergenic eczematous contact dermatitis (AECD) and asthma. Native to the Caribbean, it has been spread unintentionally to Vanuatu, 
the Seychelles, Mauritius (Parsons \& Cuthbertson 1992) and Hawai'i (Wagner et al. 1990).

\section{Animal health}

The Australian brushtail possum (Trichosurus vulpecula), introduced to New Zealand, poses a potentially great economic threat to the country through transmission of bovine tuberculosis to cattle and deer. As a result, millions of dollars are spent every year to combat the possums (Clout 1999).

A number of nematode parasites have been identified in the coqui (Dyer et al. 1995; see previous case study on the coqui), and it is feasible that these or other vertebrate parasites could be transmitted to indigenous wildlife (see Goldberg \& Bursey 2000).

\section{Governance}

The hibiscus mealy bug (Maconellicoccus hirsutus) attacks more than 200 plant species and is a serious pest in many tropical and subtropical regions, including Africa, South-east Asia and northern Australia (Wittenburg \& Cock 2001). In the Caribbean, the insect has caused more than US\$ 60 million in direct losses to agriculture and has cost more than US\$ 1 million to control (Hernandez et al. 2002). The insect reportedly invaded Grenada in 1993 through an unintentional introduction, but was not officially recorded until late 2004 (FAO [Food and Agriculture Organization of the United Nations] 1995). The government may have lost a national election during the height of the infestation because it was deemed too slow in responding to the problem (M. Kairo, personal communication 2003).

\section{Costs}

Prevention is by far the most cost effective means to minimize the spread and consequences of IAS (NRC 2002). If, however, prevention systems are inadequate, and newly introduced IAS are not detected and eradicated before they become established and spread, the costs of reactive management can become onerous and require funds needed for other societal demands. The following examples illustrate the costs of eradication and control of IAS on islands.

- Eradication of the Mediterranean fruit fly (Ceratitis capitata) detected in New Zealand in 1996 cost approximately NZ\$ 6 million (Allwood et al. 2002).

- The Institute for Wildlife Studies' costs for removing feral pigs from Santa Catalina Island (California, USA) during 1990-2001 amounted to US\$ 3175517 (Schuyler et al. 2002).

- The initial stages of a rapid response programme for the yellow crazy ant (Anoplolepis gracilipes) in Christmas Island National Park cost AUD\$ 1.5 million over 2002-2003 (M. Jeffrey, Parks Australia, personal communication 2003).

- In Hawai'i, the intentionally introduced alga Hypnea musciformis costs more than US\$100 000 per year to remove from Kihei beaches, and $>$ US $\$ 20$ million per year in loss of rental income, decreases in property value and clean up in north Kihei (Meyerson \& Reaser 2003).

\section{Ecological and socioeconomic impacts}

Environmental consequences translate into socioeconomic impacts when they influence the ability of ecosystems to provide goods and services for humanity. Some species have direct effects across a variety of ecological features and socioeconomic sectors.

The brown tree snake (Boiga irregularis) is native to eastern Indonesia, the Solomon Islands, New Guinea, as well as the northern and eastern coasts of Australia. It was first sighted in Guam in the early 1950s, having probably arrived amidst ship cargo from a small island (Manus) in Papua New Guinea. Within 30 years it had spread throughout Guam's $523 \mathrm{~km}^{2}$, and more than 5000 snakes can now be found per $\mathrm{km}^{2}$ in some forested areas. The snake has extirpated nearly all the native birds on the island; only three of 12 native bird species survive in the wild and one is on the verge of extinction (Savidge 1987). It has also severely affected small reptile and mammal populations, including the threatened Mariana fruit bat (Pteropus mariannus). The arboreal snakes often move along power lines, frequently causing power outages, equipment damage, and consequent problems ranging from food spoilage to computer failure. The snakes also eat wildlife, poultry, eggs and pets, and will attack humans, some affected children requiring hospitalization and intensive care (Fritts 1998; Wittenberg \& Cock 2001; Shine et al. 2003a).

From both an ecological and socioeconomic perspective, ants are probably the most harmful group of invasive insects on islands. The South American red fire ant Solenopsis wagneri $(=$ invicta $)$, recently established in California and Australia and unintentionally spread from Florida across the Bahamas and Puerto Rico to Trinidad, is a threat not just to biodiversity, but to human health (stings), electrical equipment, agriculture and human quality of life in island environments. Given the ant's ability to be transported inadvertently in cargo, it is poised to invade Hawai'i and other Pacific islands. The species is likely to prove especially damaging in archipelagos where the native fauna does not include ants (Shine et al. 2003a,b).

\section{RESPONSES}

The vulnerability of island ecosystems to the impacts of IAS has led some resource managers to consider the protection and restoration of islands as an impossible task. As a result, islands and the human communities that depend upon them have often been neglected and occasionally devastated by IAS (Loope \& Mueller-Dombois 1989). However, with the growing number of examples of successful IAS eradication and control programmes on islands and greater awareness of the problem, the capacity of countries to prevent the movement and introduction of IAS has increased. Furthermore, the small size and geographic/topographic restriction of many island ecosystems can present opportunities for the management 
of IAS that are superior to those in mainland ecosystems (Veitch \& Clout 2002).

In general, the requisite government strategies to minimize the impacts of IAS are well known. For example, GISP and its partner organizations have provided publications and guidance for developing and implementing effective strategic programmes for the prevention, eradication or control of IAS (IUCN [World Conservation Union] 2000; Sherley 2000; McNeely et al. 2001; Shine et al. 2000; Wittenberg \& Cock 2001; Veitch \& Clout 2002; Hillard 2004). Several of these publications provide case studies or recommendations for overcoming sociopolitical, financial, scientific, technical and technological challenges to the implementation of IAS prevention and management. Additional guidance has been provided to governments through decisions made by the CBD, Ramsar Convention on Wetlands and the International Maritime Organization.

Despite this knowledge base, however, the eradication of IAS from islands remains a much underused and reported conservation tool (Donlan et al. 2003). The greatest barriers to eradication are more likely to derive from a lack of human will, rather than scientific and technical challenges. For example, the USA has yet to fully implement its first National Invasive Species Management Plan (NISC [National Invasive Species Council] 2001) which calls for actions that could benefit not only Hawai'i and the USA territories, but island nations throughout the world.

In well-funded contexts, the eradication of IAS can be accomplished (Simberloff 2001; Veitch \& Clout 2002), despite initial mistakes (see Parkes 1990). Thus far, vertebrate species are the most commonly eradicated. For example, goats (Capra hircus) have been successfully eradicated from at least 120 islands worldwide (Campbell \& Donlan 2005), feral cats (Felis silvestris catus) have been eradicated from at least 48 islands (Nogales et al. 2004), the largest pig (Sus scrofa) eradication was recently accomplished in the Galápagos (Cruz et al. 2005) and, in Europe, a total of 37 eradication programmes have successfully eliminated rats (mostly Rattus norvegicus), North American mink (Mustela vison), goats (Capra hircus) and cats (Felis silvestris catus) (Genovesi 2005).

However, any plan to eradicate or control IAS on islands needs to consider the potential impacts of the proposed actions on island ecosystems and the people that depend upon them. Undertaken with inadequate consideration of ecosystem linkages, eradication and control programmes can create additional problems and lose requisite public and institutional support.

If not species-specific or properly handled and applied, some pesticides can threaten animal (wild and domestic) and human health, or both. For example, an attempt to eradicate rats from Fregate Island (Seychelles) was abandoned when several critically endangered Seychelles magpie-robins died from secondary rodenticide poisoning. Accidental spillage of tonnes of the toxin Brodifacoum into near-shore waters in New Zealand occurred when the pesticide was being transported for a rat eradication programme on Campbell Island (Thorsen et al. 2000).

Although purposeful introductions of organisms for biological control have led to notable successes in controlling IAS on islands (Waterhouse \& Norris 1989), biocontrol agents have occasionally exerted unanticipated negative environmental effects. Examples include the rosy wolf snail (Euglandina rosea) on Pacific islands (Hadfield et al. 1993), alien parasitoids in Hawai'i (Henneman \& Memmott 2001) and the Indian mongoose (Herpestes auropunctatus) in the Pacific and Caribbean where it has caused extinctions of island reptiles and birds (Courchamp et al. 2003).

The invasion of alien species is a consequence of human activities and an issue that affects all sectors of society. Humans are the facilitators both of the problem and solutions (McNeely 2001). Because of the relatively small size of the human populations on some islands and the communitybased structure typical of many SIDS, island systems provide scientists, natural resource managers and policy makers with particularly important opportunities to engage indigenous and local communities in programmes to minimize the impacts of IAS (Shine et al. 2003a, b; Pallewatta et al. 2004a, b).

\section{CONCLUSIONS}

Biological invasions have the potential to arise anywhere and efforts to combat them are fraught with uncertainties. Thus, it is a challenge for ecologists, economists, and others to develop and implement rigorous risk analysis frameworks and environmental impact assessments for IAS. Furthermore, because the issue of IAS is new to many sectors and governments, there is a paucity of data to incorporate into appropriate analyses. For these reasons, it can be difficult to predict the vulnerability of an island ecosystem to IAS, as well as to determine the impacts that IAS may have had or that may be in progress. Nevertheless, sufficient evidence has emerged that IAS may now be the most significant drivers of population declines and species extinctions in island ecosystems worldwide (Veitch \& Clout 2002; Donlan et al. 2003). Clearly, IAS can also have significant socioeconomic impacts either directly (for example on human health) or indirectly through their effects on ecosystem goods and services. Failure to adequately prevent and minimize the impacts of IAS will undoubtedly result in a 'piling up of new human difficulties' (Elton 1958).

The measures needed to prevent and minimize the impacts of IAS on island ecosystems are generally known, although more research would doubtless pay substantial dividends. However, many island nations and territories lack the scientific and technical information, infrastructure and human and financial resources necessary to adequately address the problems caused by IAS (Barnard \& Waage 2004). Furthermore, biological invasions and the severity of their consequent impacts are likely to be facilitated by land use and climate change in unprecedented ways (Dukes \& Mooney 1999). 
Although the prevention, eradication and control of IAS on islands (and in other ecosystems) present scientific, political and ethical challenges, the problem can be substantially reduced through concerted action. Stakeholders need to be made aware of the problem and motivated to address it. Scientifically-based information and effective tools need to be provided to policy makers and resource managers so that wellinformed decisions can be enacted. Cooperative programmes need to be forged among governments and other institutions to enable the problem to be addressed in a strategic, holistic and timely manner.

\section{ACKNOWLEDGEMENTS}

The Convention on Biological Diversity and the US Agency for International Development funded this review. The US Environmental Protection Agency, National Fish and Wildlife Foundation, Smithsonian Institution and Bishop Museum provided in-kind support. We thank three anonymous reviewers and Nicholas Polunin for useful comments, and Alison Bentley for her patience and support as manuscript shepherd.

\section{References}

Alcover, J.A., Sans, A. \& Palmer, M. (1998) The extent of extinctions of mammals on islands. Fournal of Biogeography 25: 913-918.

Allwood, A.J, Vueti, E.T., Leblanc, L. \& Bull, R. (2002) Eradication of introduced Bactrocera species (Dipera: Tephritidae) in Nauru using make annihilation and protein bait application techniques. In: Turning the Tide: the Eradication of Invasive Species, ed. C.R. Veitch \& M.N. Clout, pp. 19-25. Gland, Switzerland and Cambridge, UK: IUCN Species Specialist Group.

Aplet, G.H. (1990) Alteration of earthworm community biomass by the alien Myrica faya in Hawaii. Oecologia 82: 414-416.

Bailey-Brock, J.H. \& Ringwood, A. (1982) Methods for the control of the mud blister worm, Polydora mebsteri, in Hawaiian oyster culture. Sea Grant Quarterly 4: 1-6.

Barnard, P. \& Waage, J. (2004) Tackling Biological Invasions Around the World: Regional Responses to the Invasive Alien Species Threat. Cape Town, South Africa: The Global Invasive Species Programme.

Binggeli, P. (1996) A taxonomic, biogeographical and ecological overview of invasive woody plants. Fournal of Vegetation Science 7 : 121-124.

Blackburn, T.M. \& Duncan, R.P. (2001) Determinants of establishment success in introduced birds. Nature 414: 195-197.

Blumenthal, D. (2005) Interrelated causes of plant invasion. Science 310: 243-244.

Bramwell, D. \& Bramwell, Z.I. (1974) Wildflowers of the Canary Islands. London, UK: Tornes.

Burbidge, A.A. \& Manly, B.F.J. (2002) Mammal extinctions on Australian islands: causes and conservation. Fournal of Biogeography 29: 465-473.

Burgiel, S., Foote, G., Orellana, M. \& Perrault, A. (2006) Invasive Alien Species and Trade: Integrating Prevention Measures and International Trade Rules. Washington, DC, USA: Center for International Environmental Law and Defenders of Wildlife.
Campbell, K. \& Donlan, C.J. (2005) Feral goat eradications on islands. Conservation Biology 19: 1362-1374.

Carlquist, S. (1965) Island Life: A Natural History of the Islands of the World. Garden City, New York, USA: Natural History Press.

Carlquist, S. (1974) Island Biology. New York, USA: Columbia University Press.

Carlton, J.T. (2001) Introduced Species in US Coastal Waters: Environmental Impacts and Management Priorities. Arlington, VA, USA: Pew Oceans Commission.

Carr, G.D., Powell, E.A. \& Kyhos, D.W. (1986) Self-incompatibility in the Hawaiian Madinnae (Compositae): an exception to Baker's rule. Evolution 40: 430-434.

CBD (2002) Decision VI/23: Alien Species that Threaten Ecosystems, Habitats, and Species. The Hague, the Netherlands: Convention on Biological Diversity.

Chapin, F.S., Zavaleta, E.S., Viner, V.T., Naylor, R.L., Vitousek, P.M., Sala, O.E., Reynolds, H.L., Hooper, D.U., Mack, R., Diaz, S.E., Hobbie, S.E. \& Lavorel, S. (2000) Consequences of changing biodiversity. Nature 405: 234-242.

Cheke, A.S. (1987) An ecological history of the Mascarene Islands, with particular reference to extinctions and introductions of land vertebrates. In: Studies of Mascarene Island Birds, ed. A.W. Diamond, pp. 5-89. Cambridge, UK: Cambridge University Press.

Chown, S.L., Hull, B. \& Gaston, K.J. (2005) Human impacts, energy availability, and invasion across Southern Ocean Islands. Global Ecology and Biogeography 14: 521-528.

Clout, M. (1999) Biodiversity conservation and the management of invasive animals in New Zealand. In: Invasive Species and Biodiversity Management. Proceedings of the Normay/UN Conference on Alien Species, Trondheim, Norway, 1-5 fuly 1996, ed. O.T. Sandlund, P. Schei \& Å. Viken. The Netherlands: Kluwer Academic Publishers.

Clout, M.N. \& Veitch, C.R. (2002) Turning the tide of biological invasion: the potential for eradicating invasive species. In: Turning the Tide: the Eradication of Invasive Species, ed. C.R. Veitch \& M.N. Clout, pp. 1-3. Gland, Switzerland and Cambridge, UK: IUCN Species Specialist Group.

Colautti, R.I., Muirhead, J.R., Biswas, R.N. \& MacIssac, H.J. (2005) Realized versus apparent reduction in enemies of the European starling. Biological Invasions 7: 723-732.

Cole, F.R., Medeiros, A.C., Loope, L.L. \& Zuehlke, W.W. (1992) Effects of the Argentine ant on arthropod fauna of Hawaiian highelevation shrubland. Ecology 73: 1313-1322.

Coote, T. \& Loeve, E. (2003) From 61 species to five: endemic tree snails of the Society Islands fall prey to an ill-judged biological control programme. Oryx 37: 91-96.

Courchamp, F., Chapuis, J. \& Pascal, M. (2003) Mammal invaders on islands: impact, control and control impact. Biological Reviem 78: 347-383.

Cruz, F, Donlan, C.J., Campbell, K. \& Carrion, V. (2005) Conservation action in the Galápagos: feral pig (Sus scrofa) eradication from Santiago Island. Biological Conservation 121: 473-478.

Cuddihy, L.W. \& Stone, C.P. (1990) Alteration of Native Hamaiian Vegetation. Honolulu, Hawai'i, USA: University of Hawaii Cooperative National Park Resources Studies Unit.

Daily, G., ed. (1997) Nature's Services: Societal Dependence on Natural Ecosystems. Washington, DC, USA: Island Press.

D'Antonio, C. (2000) Fire, plant invasions, and global changes. In: Invasive Species in a Changing World, ed. H.A. Mooney \& R.J. Hobbs, pp. 65-93. Washington, DC, USA: Island Press. 
D’Antonio, C.M. \& Dudley, T.L. (1995) Biological invasions as agents of change on islands compared with mainlands. In: Biological Diversity and Ecosystem Function, ed. P.M. Vitousek, L. Loope \& H. Adserson, pp. 103-121. Berlin, Germany: SpringerVerlag.

D'Antonio, C.M. \& Kark, S. (2002) Impacts and extent of biotic invasions in terrestrial ecosystems. Trends in Ecology and Evolution 17: 202-204.

D’Antonio, C.M. \& Vitousek, P.M. (1992) Biological invasions by exotic grasses, the grass/fire cycle, and global change. Annual Reviem of Ecology and Systematics 23: 63-87.

Daszak, P., Cunningham, A. \& Hyatt, A.D. (2000) Emerging infectious diseases of wildlife: threats to biosecurity and human health. Science 287: 443-449.

Demopoulous, A.W.J. \& Smith, C.R. (2001) Impact of invading mangroves on Hawaiian soft-sediment communities. In: International Conference on Marine Biological Invasions, pp. 3031. New Orleans, Louisiana, USA: Louisiana Sea Grant.

Denslow, J.S. (2003) Weeds in paradise: thoughts on the invisibility of tropical islands. Annals of the Missouri Botanic Garden 90: 119127.

Desender, K., Baert, L., Maelfait, J.-P. \& Verdyck, P. (1999) Conservation on Volcan Alcedo (Galápagos): terrestrial invertebrates and the impact of introduced feral goats. Biological Conservation 87: 303-310.

Donazar, J.A., Gangoso, L., Forero, M.G. \& Juste, J. (2005) Presence, richness, and extinction of birds of prey in the Mediterranean and Macaronesian islands. Fournal of Biogeography 32: 1701-1713.

Donlan, C.J., Tershy, B.R., Campbell, K. \& Cruz, F. (2003) Research for requiems: the need for more collaborative action in eradication of invasive species. Conservation Biology 17: 1850-1851.

Drake, J.M. \& Lodge, D.M. (2006) Allee effects, propagule pressure and the probability of establishment: risk analysis for biological invasions. Biological Invasions 8: 365-375.

Duggan, I.C., Rixon, C.A.M. \& McIssac, H.J. (2006) Popularity and propagule pressure: determinants of the introduction and establishment of aquarium fish. Biological Invasions 8: 377382.

Dukes, J.S. \& Mooney, H.A. (1999) Does global change increase the success of biological invaders? Trends in Ecology and Evolution 14: 135-139.

Duncan, R.P. (1997) The role of competition and introduction effort in the success of passeriform birds introduced to New Zealand. American Naturalist 149: 903-915.

Dyer, W.G., Williams Jr, E.H. \& Williams, L.B. (1995) Nematode parasites of a Puerto Rican tree frog, Eleutherodactylus coqui. Transactions of the Illinois State Academy of Science 88: 3941.

Elton, C.S. (1958) The Ecology of Invasions by Animals and Plants. London, UK: Metheun.

Environment Agency (1999) Report on the investigation of the mongoose for eradication on Amami Island, Japan. Environment Agency, Tokyo, Japan: $51 \mathrm{pp}$.

Ewel, J.J., O’Dowd, D.J., Bergelson, J., Daehler, C.C., D’Antonio, C.M., Gomez, L.D., Gordon, D.R., Hobbs, R.J., Holt, A., Hopper, K.R., Hughes, C.E., LaHart, M., Leakey, R.R.B., Lee, W.G., Loope, L.L., Lorence, D.H., Louda, S.M., Lugo, A.E., McEvoy, P.B., Richardson, D.M. \& Vitousek, P.M. (1999) Deliberate introductions of species: research needs. BioScience 49: 619-630.
FAO (1995) Special Alert No. 263 - The Caribbean - 20 December 1995. FAO Corporate Document Repository, Economic and Social Department, FAO, Rome, Italy.

Feare, C. (1999) Ants take over from rats on Bird Island, Seychelles. Bird Conservation International 9: 95-96.

Floate, K.D. \& Whitham, T.G. (1993) The 'hybrid bridge' hypothesis: host shifting via plant hybrid swarms. American Naturalist 141: 651-662.

Fritts, T.H. (1998) The brown tree snake, Boiga irregularis, a threat to Pacific islands. US Fish and Wildlife Service Biological Report 88(31), Washington, DC, USA.

Gabriel, A.G.A., Chown, S.L., Barendse, J., Marshall, D.J., Mercer, R.D., Pugh, P.J.A. \& Smith, V.R. (2001) Biological invasions of Southern Ocean islands: the Collembola of Marion Island as a test of generalities. Ecography 24: 421-430.

Gaston, K.J., Jones, A.G., Hanel, C. \& Chown, S.L. (2003) Rates of species introduction to a remote oceanic island. Proceedings of the Royal. Society of London B 270: 1091-1098.

Genovesi, P. (2005) Eradications of invasive alien species in Europe: a review. Biological Invasions 7: 127-133.

GISP (2006) Invasive Species and Poverty: Exploring the Links. Capetown, South Africa: The Global Invasive Species Programme.

Goldberg, S.R. \& Bursey, C.R. (2000) Transport of helminths to Hawaii via the brown anole, Anolis sagrei (Polychrotidae). Fournal of Parasitology 86: 750-755.

Green, P.T., Lake, P.S. \& O'Dowd, D.J. (1999) Monopolization of litter processing by a dominant land crab on a tropical oceanic island. Oecologia 119: 435-444.

Green, P.T., Lake, P.S. \& O'Dowd, D. (2004) Resistance of island rainforest to invasion by alien plants: influence of microhabitat and herbivory on seedling performance. Biological Invasions 6: $1-9$.

Grigg, R.W. (2004) Harvesting impacts and invasion by an alien species decrease estimates of black coral yield off Maui, Hawaii. Pacific Science 58: 1-6.

Hadfield, M.G., Miller, S.E. \& Carwile, A.H. (1993) Decimation of endemic Hawaiian tree snails by alien predators. American Zoologist 33: 610 .

Hamman, O. (2004) On vegetation, recovery, goats and giant tortoises on Pinta Island, Galápagos, Ecuador. Biodiversity and Conservation 2: 138-151.

Harrington, R.A. \& Ewel, J.J. (1997) Invasibility of tree plantations by native and non-indigenous plant species in Hawaii. Forest Ecology and Management 99: 153-162.

HEAR (2000) Alien Caribbean Frogs in Hamaii: Problematic Frogs Trouble People, Environment. Honolulu, Hawai'i, USA: Hawaiian Ecosystems at Risk Project.

Henneman, M.L. \& Memmott, J. (2001) Infiltration of a Hawaiian community by introduced biological control agents. Science 293: 1314-1316.

Hernandez, G., Lahmann, E. \& Perez-Gil, R. (2002) Invasores en Mesoamerica y el Caribe: Invasives in Mesoamerica and the Caribbean. San Jose, Costa Rica: IUCN.

Hillard, R. (2004) Best Practices for the Management of Introduced Marine Pests: A Reviem. Cape Town, South Africa: The Global Invasive Species Programme.

IUCN (2000) Guidelines for the Prevention of Biodiversity Loss Caused by Alien Invasive Species. Gland, Switzerland: IUCN.

Johnson, T.H. \& Stattersfield, A.J. (1990) A global review of island endemic birds. Ibis 132: 167-180. 
Joshi, R.C. \& Sebastian, L.S. (2006) Global Advances in the Ecology and Management of Golden Apple Snails. Laguna, Philippines: Department of Agriculture-Cordillera Administrative Region, Cordillera Highland Agricultural Resource Management Project, and Philippine Rice Research Institute Agricultural Librarians Association of Philippines.

Kagoshima Prefecture Office (1999) Annual Report of the Control of the Habu. Tokyo, Japan: Kagoshima Prefecture Office.

Kishida, K. (1931) Professor Watase and import of mongoose. Zoological Science 43: 70-78.

Kolar, C.S. \& Lodge, D.M. (2002) Ecological predictions and risk assessment for alien fishes in North America. Science 298: 12331236.

Kraus, F., Campbell III, E.W., Allison, A. \& Pratt, T. (1999) Eleutherodactylus frog introductions to Hawaii. Herpetological Reviem 30: 21-25.

Kuschel, G., ed. (1975) Biogeography and Ecology in Nem Zealand. Monographie Biologicae, Volume 27. The Hague, Netherlands: Junk.

Lake, P.S. \& O'Dowd, D.J. (1991) Red crabs in rain forest, Christmas Island: biotic resistance to invasion by the giant African land snail. Oikos 62: 25-29.

Leung, B., Lodge, D.M., Finnoff, D., Shogren, J.F., Lewis, M.A. \& Lamberti, G. (2002) An ounce of prevention or a pound of cure: bioeconomic risk analysis of invasive species. Proceedings of the Royal Society of London 269: 2407-2413.

Levin, D.A., Francisco-Ortega, J. \& Jansen, R.K. (1996) Hybridization and the extinction of rare species. Conservation Biology 10: 10-16.

Lockwood, J.L., Cassey, P. \& Blackburn, T. (2005) The role of propagule pressure in explaining species invasions. Trends in Ecology and Evolution 20: 223-228.

Lo Re, V. \& Gluckman, S.J. (2003) Eosinophilic meningitis. American Fournal of Medicine 114: 217-223.

Lonsdale, M.W. (1999) Global patterns of plant invasions and the concept of invasibility. Ecology 80: 1522-1536.

Loope, L.L. \& Mueller-Dombois, D. (1989) Characteristics of invaded islands, with special reference to Hawaii. In: Biological Invasions: A Global Perspective, ed. J.A. Drake, H.A. Mooney, F. di Castri, R.H. Groves, F.J. Kruger, M. Rejmanek \& M. Williamson, pp. 257-280. Scientific Committee on Problems of the Environment (SCOPE) 37. New York, NY, USA: John Wiley and Sons.

Mack, M. \& D'Antonio, C.M. (1998) Impacts of biological invasions on disturbance regimes. Trends in Ecology and Evolution 13: 195 198.

Mack, R.N., Simberloff, D., Lonsdale, W.M., Evans, H., Clout, M. \& Bazzaz, F.A. (2000) Biotic invasions: causes, epidemiology, global consequences and control. Ecological Applications 10: 689710 .

MacDonald, I., Reaser, J.K., Bright, C., Neville, L., Murphy, S. \& Preston, G., eds (2004a) Prevention and Management of Invasive Alien Species: Proceedings of a Workshop on Forging Cooperation throughout Southern Africa. Cape Town, South Africa: Global Invasive Species Programme.

MacDonald, I., Reaser, J.K., Bright, C., Neville, L., Murphy, S. \& Preston, G., eds (2004b) Invasive Alien Species in Southern Africa: National Reports and Directory of Resources. Cape Town, South Africa: Global Invasive Species Programme.

Magee, J., McMullen, C.K., Reaser, J.K., Spitzer, E., Struve, S., Tufts, C., Tye, A. \& Woodruff, G. (2001) Green invaders of the Galápagos Islands. Science 294: 1279-1280.
Mauremooto, J.R., ed. (2003) Proceedings of the Regional Workshop on Invasive Alien Species and Terrestrial Ecosystem Rehabilitation for Western Indian Ocean Island States: Sharing Experience, Identifying Priorities and Defining Foint Action. Cape Town, South Africa: The Global Invasive Species Programme.

McChesney, G.J. \& Tershy, B.R. (1998) History and status of introduced mammals and impacts to breeding seabirds on the California Channel and Northwestern Baja California islands. Colonial Waterbirds 21: 335-347.

McMullen, C.K. (1999) Flomering Plants of the Galápagos. Ithaca, NY, USA: Cornell University Press.

McNeely, J., ed. (2001) The Great Reshuffling: Human Dimensions of Invasive Alien Species. Gland, Switzerland: IUCN.

McNeely, J.A., Mooney, H.A., Neville, L.E., Schei, P.J. \& Waage, J.K., eds (2001) Global Strategy on Invasive Alien Species. Cambridge, UK: IUCN in collaboration with the Global Invasive Species Programme.

MEA (2005) Ecosystems and Human Well-being: Biodiversity Synthesis. Washington, DC, USA: World Resources Institute.

Meyer, J.-Y. \& Florence, J. (1996) Tahiti's flora endangered by the invasion of Miconia calvescens DC. (Melastomataceae). Fournal of Biogeography 23: 775-781.

Merton, D., Climo, G., Laboudallon, V., Robert, S. \& Mander, C. (2002) Alien mammal eradication and quarantine on inhabited islands. In: Turning the Tide: the Eradication of Invasive Species, ed. C.R. Veitch \& M.N. Clout, pp. 226-232. Gland, Switzerland and Cambridge, UK: IUCN Species Specialist Group.

Meyerson, L.A. \& Reaser, J.K. (2002) Biosecurity: moving toward a comprehensive approach. BioScience 52: 593-600.

Meyerson, L.A. \& Reaser, J.K. eds. (2003) The Ecological and Socioeconomic Impacts of Invasive Alien Species on Island Ecosystems: Results of an Experts Consultation. Washington, DC, USA: The Global Invasive Species Programme (GISP) on behalf of the Convention on Biological Diversity.

Milberg, P. \& Tyrberg, T. (1993) Naïve birds and noble savages: a review of man-caused prehistoric extinctions of island birds. Ecography 16: 229-250.

Mooney H.A. \& Hobbs R.J.s, eds. (2000) Invasive Species in a Changing World. Washington, DC, USA: Island Press.

Mueller-Dombois, D. (1981) Island ecosystems: what is unique about their ecology? Island Ecosystems: Biological Organisation in Selected Hamaiian Communities, ed. D. Mueller-Dombois, K.W. Bridges \& H.L. Carson, pp. 485-501. Woods Hole, Massachusetts, USA: Hutchinson Ross Publishing Company.

Mueller-Dombois, D. \& Spatz, G. (1975) The influence of feral goats on the lowland vegetation in Hawaii Volcanoes National Park. Phytocoenologica 3: 1-29.

Naylor, R. (1996) Invasions in agriculture: assessing the cost of the golden apple snail in Asia. Ambio 25: 443-448.

NISC (2001) National Invasive Species Management Plan. Washington, DC, USA: National Invasive Species Council.

Nogales, M., Martín, A., Tershy, B.R., Donlan, C.J., Veitch, D., Puerta, N., Wood, B. \& Alonso, J. (2004) A review of feral cat eradication on islands. Conservation Biology 18: 310-319.

NRC (2002) Predicting Invasions of Nonindigenous Plants and Plant Pests. Committee on the Scientific Basis for Predicting the Invasive Potential of Nonindigenous Plants and Plant Pests in the United States. Washington, DC, USA: National Academy Press.

O'Dowd, D.J., Green, P.T. \& Lake, P.S. (2003) Invasional 'meltdown' on an oceanic island. Ecology Letters 6: 812-817.

Pallewatta, N., Reaser,J.K. \& Gutierrez, A.T., eds (2004a) Prevention and Management of Invasive Alien Species: Proceedings of a 
Workshop on Forging Cooperation throughout South-Southeast Asia. Cape Town, Republic of South Africa: The Global Invasive Species Programme.

Pallewatta, N., Reaser, J.K. \& Gutierrez, A.T., eds. (2004b) Invasive Alien Species in South-Southeast Asia: National Reports and Directory of Resources. Cape Town, Republic of South Africa: The Global Invasive Species Programme.

Parker, I.M., Simberloff, D., Lonsdale, W.M., Goodell, K., Wonham, M., Kareiva, P.M., Williamson, M.H., Holle, B.V., Moyle, P.B., Byers, J.E. \& Goldwasser, L. (1999) Impact: toward a framework for understanding the ecological effects of invaders. Biological Invasions 1: 3-19.

Parkes, J.P. (1990) Feral goat control in New Zealand. Biological Conservation 54: 335-348.

Parr, S.J., Hill, M.J., Nevill, J., Merton, D.V. \& Shah, N.J. (2000) Alien species case-study: eradication of introduced mammals in Seychelles in 2000. Report to the CBD Secretariat, IUCN, Gland, Switzerland.

Parsons, W.T. \& Cuthbertson, E.G. (1992) Noxious Weeds of Australia. Melbourne, Australia: Inkata Press.

Perrings, C., Williamson, M. \& Dalmazzone, S., eds (2000) The Economics of Biological Invasions. Northampton, MA, USA: Edward Elgar.

Pimentel, D., ed. (2002) Biological Invasions: Economic and Environmental Costs of Alien Plant, Animal, and Microbe Species. Washington, DC, USA: CRC Press.

Pimentel, D., McNair, S., Janecka, J, Wightman, J., Sommonds, C., O'Connell, C., Wong, E., Russel, L., Zern, J., Aquino, T. \& Tsomondo, T. (2001) Economic and environmental threats of alien plant, animal, and microbe invasions. Agriculture, Ecosystems and Environment 84: 1-20.

Reaser, J.K., Neville, L.E. \& Svart, H.E., eds (2002) Management of Invasive Alien Species: Forging Cooperation in the Baltic/Nordic Region. Palo Alto, CA, USA: The Global Invasive Species Programme.

Reaser, J.K., Yeager, B.B., Phifer, P.R., Hancock, A.K. \& Gutierrez, A.T. (2003a) Environmental diplomacy and the global movement of invasive alien species: a US perspective. In: Invasive Species: Vectors and Management Strategies, ed. G.M. Ruiz. \& J.T. Carlton, pp. 362-381. Washington, DC, USA: Island Press.

Reaser, J.K., Gutierrez, A.T. \& Meyerson, L.A. (2003b) Biological invasions: do the costs outweigh the benefits? BioScience 53: 598599.

Rhymer, J.M. \& Simberloff, D. (1996) Extinction by hybridization and introgression. Annual Reviem of Ecology and Systematics 27: $83-110$.

Ruiz, G. \& Carlton, J., eds (2004) Invasive Species: Vectors and Management Strategies. Washington, DC, USA: Island Press.

Sala, O.E., Chapin III, F.S., Armesto, J.J., Berlow, E., Bloomfield, J., Dirzo, R., Huber-Sanwald, E., Huenneke, L.F., Jackson, R.B., Kinzig, A., Leemans, R., Lodge, D.M., Mooney, H.A., Oesterheld, M., Poff, N.L., Sykes, M.T., Walker, B.H., Walker, M. \& Hall, D.H. (2000) Global biodiversity scenarios for the year 2100. Science 287: 1770-1774.

Sara, M. \& Morand, S. (2002) Island incidence and mainland population density: mammals from Mediterranean islands. Diversity and Distributions 8: 1-9.

Savidge, J.A. (1987) Extinction of an island forest avifauna by an introduced snake. Ecology 68: 660-668.

Schuyler, P.T., Garcelon, D.K. \& Escover, S. (2002) Eradication of feral pigs (Sus scrofa) on Santa Catalina Island, California, USA. In: Turning the Tide: the Eradication of Invasive Species, ed. C.R. Veitch. \& M.N. Clout, pp. 274-286. Gland, Switzerland and Cambridge, UK: IUCN Species Specialist Group.

Schwartz, A. \& Henderson, R.W. (1991) Amphibians and Reptiles of the West Indies: Descriptions, Distributions, and Natural History. Gainesville, FL, USA: University of Florida Press.

Sealey, N. (2006) The cycle of Casuarina-induced beach erosion a case study from Andros, Bahamas. In: Proceedings of the 12th Symposium on the Geology of the Bahamas and other Carbonate Regions, 2004, ed. D. Gamble, pp. 197-205. San Salvador: Gerace Research Center.

Sekiguchi, K., Inoue, F., Ueda, T., Ogura, G. \& Kawashima, Y. (2001) Genealogical relationship between introduced mongooses in Okinawa and Amamiohsima Islands, Ryukyu Archipelago, inferred from sequences of mtDNA cytochrome $b$ gene. Honyur Kagaku 41: 65-70.

Sherley, G., ed. (2000) Invasive Species in the Pacific: A Technical Reviem and Draft Regional Strategy. Apia, Samoa: South Pacific Regional Environment Programme.

Shine, C., Williams, N. \& Gundling, L. (2000) A Guide to Designing Legal and Institutional Framemorks on Alien Invasive Species. Cambridge, UK: IUCN.

Shine, C., Reaser, J.K. \& Gutierrez, A.T. (2003a) Prevention and Management of Invasive Alien Species: Proceedings of a Workshop on Forging Cooperation throughout the Austral-Pacific. Cape Town, Republic of South Africa: The Global Invasive Species Programme.

Shine, C., Reaser, J.K. \& Gutierrez, A.T., eds (2003b) Invasive Alien Species in the Austral Pacific: National Reports and Directory of Resources. Cape Town, Republic of South Africa: The Global Invasive Species Programme.

Simberloff, D. (1986) Introduced insects: a biogeographic and systematic perspective. In: Ecology of Biological Invasions of North America and Hamaii, ed. H.A. Mooney \& J.A. Drake, pp. 3-26. New York, USA: Springer-Verlag.

Simberloff, D. (1995) Why do introduced species appear to devastate islands more than mainland areas? Pacific Science 49: 87-97.

Simberloff, D. (2000a) No reserve is an island: marine reserves and nonindigenous species. Bulletin of Marine Science 66: 567-580.

Simberloff, D. (2000b) Extinction-proneness of island species: causes and management implications. Raffles Bulletin of Zoology 48: $1-9$.

Simberloff, D. (2001) Eradication of island invasives: practical actions and results achieved. Trends in Ecology and Evolution 16: 273-274.

Simon, C. (1987) Hawaiian evolutionary biology: an introduction. Trends in Ecology and Evolution 2: 175-178.

Sol, D. (2000) Are islands more susceptible to being invaded than continents? Birds say no. Ecography 23: 687-692.

Stachowicz, J.J., Whitlatch, R.B. \& Osman, R.W. 1999. Species diversity and invasion resistance in a marine ecosystem. Science 286: $1577-1579$.

Staples, G.W. \& R.H Cowie (2001) Hamai'i's Invasive Species. Honolulu, Hawai'i, USA: Bishop Museum.

Stein, B.A. \& Flack, S.R., eds (1996) America's Least Wanted: Alien Species Invasions of US Ecosystems. Washington, DC, USA: The Nature Conservancy.

Stone, C.P. \& Loope, L.L. (1987) Reducing negative effects of introduced animals on native biota in Hawaii: what is being done, what needs doing, and the role of national parks. Environmental Conservation 14: 245-258.

Thorsen, M., Shorten, R., Lucking, R. \& Lucking, V. (2000) Norway rats Rattus norvegicus on Fregate Island, Seychelles: the invasion, 
subsequent eradication attempts and implications for the island's fauna. Biological Conservation 96: 1331-138.

Tye, A., Soria, M.C. \& Gardener, M.R. (2002) A strategy for Galapagos weeds. In: Turning the Tide: the Eradication of Invasive Species, ed. C.R. Veitch \& M.N. Clout, pp. 336-341. Gland, Switzerland and Cambridge, UK: IUCN Species Specialist Group.

UN (2003) World Statistics Pocketbook: Small Island Developing States. Series V, No. 24/SIDS. New York, USA: United Nations Department of Economic and Social Affairs, Statistics Division.

Veitch, C.R. \& Clout, M.N. (2002) Turning the Tide: the Eradication of Invasive Species. Gland, Switzerland and Cambridge, UK: IUCN Species Specialist Group.

Vidal, E., Medail, F., Tatoni, T., Roche, P. \& Vidal, P. (1998) Impact of gull colonies on the flora of the Riou Archipelago Mediterranean Islands of South-East France. Biological Conservation 84: 235243.
Vitousek, P.M., D’Antonio, C.M., Loope, L.L., Rejmanek, M. \& Westbrooks, R. (1997) Introduced species: a significant component of human-caused global change. New Zealand Journal of Ecology 21: 1-16.

Waage, J.K. \& Reaser, J.K. (2001) A global strategy to defeat invasive species. Science 292: 1486.

Wagner, W.L., Herbst, D.R. \& Sohmer, S.H. (1990) Manual of the Flomering Plants of Hawaii. Honolulu, Hawai'i, USA: University of Hawaii Press and Bishop Museum Press.

Waterhouse, D.F. \& Norris, K.R. (1989) Biological Control: Pacific Prospects. Supplement 1. Canberra, Australia: ACIAR.

Wilcove, D.S., Rothstien, D., Dubow, J., Phillips, A. \& Losos, E. (1998) Quantifying threats to imperiled species in the United States. BioScience 48: 607-615.

Wittenberg, R. \& Cock, M.J.W. (2001) Invasive Alien Species: A Toolkit of Best Prevention and Management Practices. Wallingford, Oxon, UK: CAB International. 